\title{
Intensification of Foam Layered Apparatus by Foam Stabilization
}

Liaposhchenko O. ${ }^{1 *}$, Khukhryanskiy O. ${ }^{1,2}$, Moiseev V. ${ }^{3}$, Ochowiak M. ${ }^{4}$, Manoilo E. ${ }^{3}$

${ }^{1}$ Sumy State University, 2 Rymskogo-Korsakova St., 40007 Sumy, Ukraine;

${ }^{2}$ PJSC "Ukrhimproekt", 13 Illinska St., 40009 Sumy, Ukraine;

${ }^{3}$ National Technical University “Kharkiv Polytechnic Institute”, 2 Kyrpychova St., 61002 Kharkiv, Ukraine;

${ }^{4}$ Poznan University of Technology, 5 M. Sklodowska-Curie Sq., 60-965 Poznan, Poland

\section{Article info:}

Paper received:

The final version of the paper received:

Paper accepted online:
July 2, 2018

October 25, 2018

October 30, 2018
"Corresponding Author's Address:

o.liaposhchenko@pohnp.sumdu.edu.ua

Abstract. In this work the expanded models are studied for foaming apparatuses with gratings made of tubes for different diameters. The problem of intensification of foam devices using coarse-grating lattices is considered. The possibility of deep cleaning and practically complete cleaning of gases from ammonia and fluoride compounds with their separate absorption is noted. The series of experimental dependencies for the main parameters of the process are given. The possibility of effective mass-exchange processes in an intensive foam layer on counter-current coarsegrating lattices is confirmed. The controversial requirements for equipment have been given despite the large number of existing machines for mass transfer processes, as well as the development of new high-intensity and efficient equipment for environmental technologies in many industries is considered.

Keywords: industrial gas emissions, hydrodynamics, mass transfer; foam apparatus, foam layer, purification process, stabilization of foam layer, intensification of the process.

\section{Introduction}

In modern conditions of significant anthropogenic environmental impact, it began the search for the most efficient and cost-effective methods of cleaning industrial emissions. Methods of cleaning and equipment that is being developed should take into account working possibilities in a wide range of working conditions.

In order to reduce energy consumption in systems for catching harmful and toxic substances, it is necessary to provide a reduction of hydraulic resistance while maintaining the high efficiency of gas streams cleaning.

Given the controversial requirements for equipment and despite the large number of existing machines for mass transfer processes, the development of new highly intensive and efficient equipment is of considerable interest to environmental protection technologies in many industries.

\section{Literature Review}

The most common method of purifying gas streams is methods for the absorption of harmful components from the released industrial gases. In this case, either the process of physical absorption occurs, or the absorbent enters a chemical interaction with the absorbed component (the process of chemisorption).

Recently, the direction associated with conducting diffuse processes in intensive regimes with developed turbulence at high speeds of gas and liquid flows has become relevant. Actually turbolization of the gas-liquid system leads to an increase in the intensity of mass-exchange devices.

One of the methods of turbination of gas-liquid systems is their transformation into mobile unstable foam due to the kinetic energy of gas.

Foam mode and foam devices of the "classical" type are described in and analyzed in the papers [1-4]. Intensified apparatuses with foam layer stabilizer have been widely used for capturing dust from gases and for gas absorption in the chemical and related industries. Due to its high efficiency, high unit capacity, good operational qualities of their application, they can improve the stages of gas purification for technological and sanitary purposes, increase the efficiency of mass transfer and the reliability of gas-cleaning equipment.

Industrial introducing the stabilization method of the gas-liquid layer significantly expands the scope of foaming devices and opens up new possibilities for intensifying technological processes with the simultaneous creation of low-waste technologies. 


\section{Research Methodology}

Based on researching the semi-industrial models of foam machines with lattices, assembled from tubes of different diameters, a pilot sample of foam absorber with the productivity of $12000 \mathrm{~m}^{3} / \mathrm{h}$ of gas was designed.

One of the research directions was the absorption of ammonia by water in intensive foam modes with a stabilized foam layer. Absorption of ammonia by water is a typical process in absorber research to detect their effectiveness.

The process of absorption of ammonia in foam mode on counterproductive gratings of the usual type is quite fully studied at gas velocities up to $2.5 \mathrm{~m} / \mathrm{s}$. In order to compare the technological parameters of ammonia absorption in water under similar conditions, the work of the most common industrial counter processing grating with an area of free intersection of $0.18 \mathrm{~m}^{2} / \mathrm{m}^{2}$ and a diameter of holes of $5 \mathrm{~mm}$ was investigated.

The research of this grating was carried out both with the stabilizer, and without it. The research was due to the need to determine the degree of effect of the stabilization of the layer and comparison with the technological parameters of the newly developed design foam apparatus, as well as the establishment of the general nature of dependencies and kinetic parameters of the absorption process $(\eta$-efficiency of the contact stage (ECS); $K s-$ mass transfer coefficient) from the following basic parameters: $W g$ - gas velocity; $L_{0}$ - irrigation density; $C_{n}$ - initial concentration; $S_{0}-$ area of the free intersection of the plate.

\section{Results}

The gas velocity in the complete section of the device has a significant effect on the height of the gas-discharge and the initial layer. Accordingly, the gas velocity significantly influences the mass transfer coefficient, and the nature of this dependence is determined by the solubility of the gas component in the fluid. The foregoing is confirmed by the experimental data given in Figure 1, dependence 6 .

When absorbing well-soluble gases (for example, ammonia), is required a low phase of contact to achieve a high degree of absorption. Reducing the contact time of phases with increasing gas velocity in foam mode is largely offset by the turbulence of the gas-liquid layer and increasing the contact of surface phases.

Previously, in studying the absorption of ammonia by water on ordinary gratings, it was found that in the gas torch the holes in the grid transmit from 50 to $90 \%$ of the total mass of matter [5]. This determines the "input" effect, that is, the most intense interaction between the gas and the liquid, which occurs at the time of forming a new contact surface. However, at a low altitude of the initial fluid layer on the grating of the usual type of apparatus it is possible to pass the gas without contact with the absorbent fluid, and as a consequence, a decrease in the absorption rate. This is especially true for industrial ma- chines. As indicated, the stabilization of the foam layer makes its structure more uniform and excludes the probability of such a state.

Investigations on new types of gratings with foam layer stabilization have shown that the efficiency of the apparatus during absorption of ammonia by water practically does not depend on the value of gas velocity (Figure 1). Moreover, ECS in the new design of the device is much higher than that of conventional gratings without stabilization and even when it is installed on ordinary type gratings.

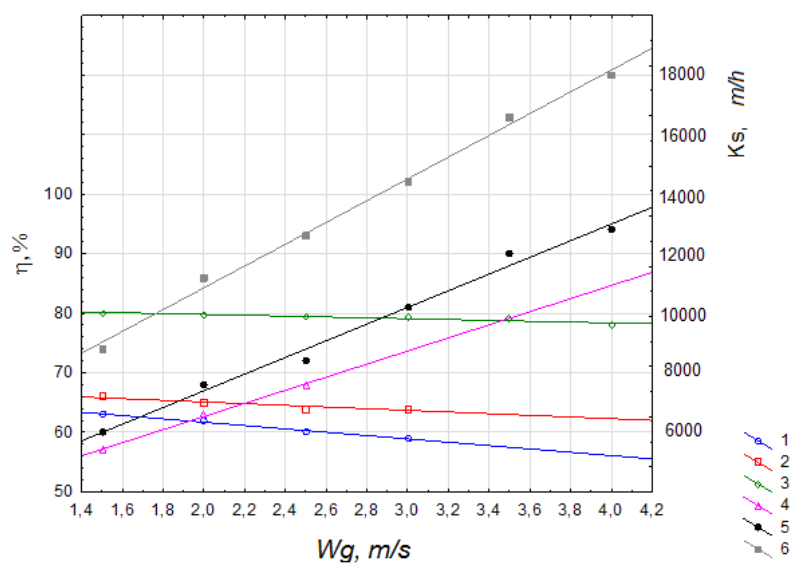

Figure 1 - Efficiency of the contact stage (1-3) and mass transfer coefficient (4-6) dependences on the gas velocity for the ammonia water system with $L_{0}=5 \mathrm{~m}^{3} /\left(\mathrm{m}^{2} \cdot \mathrm{h}\right)$ :

$1,4-d_{E}=0.005 \mathrm{~m}, S_{0}=0.18 \mathrm{~m}^{2} / \mathrm{m}^{2}-$ without stabilizer; $2,5-d_{E}=0.005 \mathrm{~m}, S_{0}=0.18 \mathrm{~m}^{2} / \mathrm{m}^{2}-$ with stabilizer; $3,6-d_{E}=0.005 \mathrm{~m}, S_{0}=0.20 \mathrm{~m}^{2} / \mathrm{m}^{2}-$ with stabilizer

It should be noted that the difference between the values of the efficiency of the contact stage and mass transfer coefficient, referenced to the unit area of the grating, depending on the gas velocity in the complete section of the apparatus on the gratings with small holes with and without the stabilizer increases at high gas. This proves the high intensity of the process and confirms the expediency of using a stabilized foam layer on large-hinged gratings for the purification of gases in the industry.

The dependence of the of the efficiency of the contact stage by absorption on the initial ammonia concentration of the comparable contact devices (Figure 2) fully confirms the conclusions made about the effectiveness of new foaming apparatus. It is important to note that in the studied limits of variation of the initial concentration of ammonia $\left(C_{n} \leq 1 \%\right.$ vol. $)$, the efficiency of the contact stage remains constant for other equal conditions. This allows using the known methods of calculating the required number of steps to achieve the desired process efficiency.

The irrigation density (Figure 3 ) affects on the efficiency of the contact stage only at low values of the $L_{0}$ to $8 \mathrm{~m}^{3} /\left(\mathrm{m}^{2} \cdot \mathrm{h}\right)$. It depends on the fact that at low irrigation density, the residence time of the liquid on the grading increases to a certain (effective) value. Further increases in irrigation density have little effect on the absorption process. 


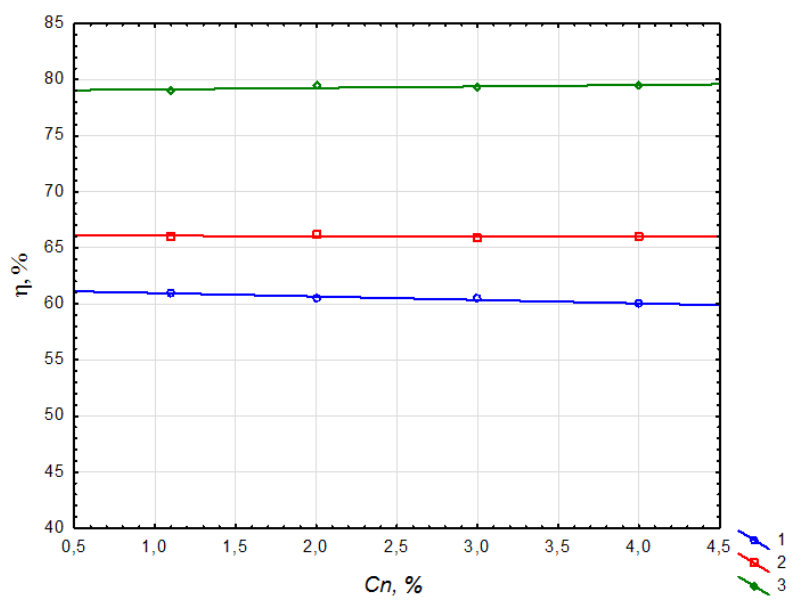

Figure 2 - Efficiency of the contact stage dependence at absorbing ammonia by water from the initial concentration of ammonia $W_{g}=2.5 \mathrm{~m} / \mathrm{s}$ and $L_{0}=5 \mathrm{~m}^{3} /\left(\mathrm{m}^{2} \cdot \mathrm{h}\right)$ with the following grates: $1-d_{E}=0.005 \mathrm{~m}, S_{0}=0.18 \mathrm{~m}^{2} / \mathrm{m}^{2}-$ without stabilizer;

$2-d_{E}=0.005 \mathrm{~m}, S_{0}=0.18 \mathrm{~m}^{2} / \mathrm{m}^{2}-$ with stabilizer;

$3-d_{E}=0.005 \mathrm{~m}, S_{0}=0.20 \mathrm{~m}^{2} / \mathrm{m}^{2}-$ with stabilizer

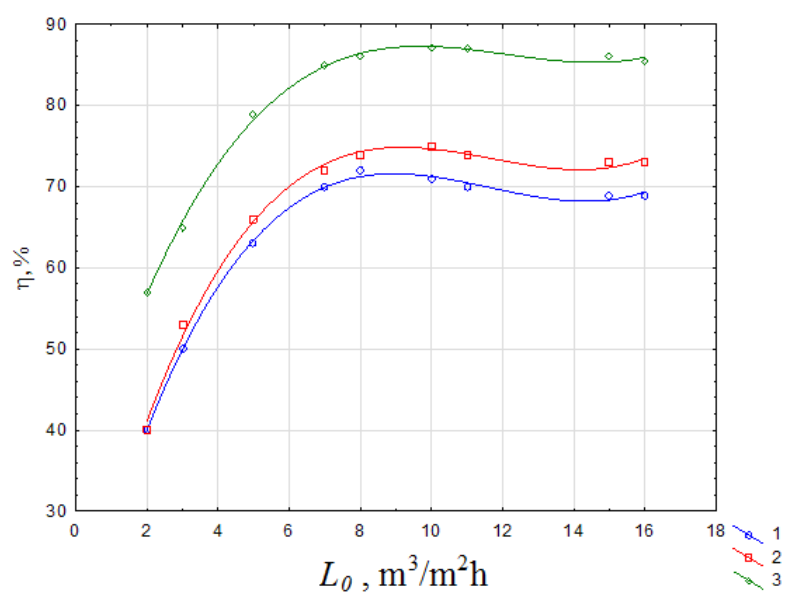

Figure 3 - Efficiency of the contact stage dependence in absorbing ammonia by water from the irrigation density: $W_{g}=2.5 \mathrm{~m} / \mathrm{s} ; C_{n}=1-2 \%$. with the following grates: $1-d_{E}=0.005 \mathrm{~m}, S_{0}=0.18 \mathrm{~m}^{2} / \mathrm{m}^{2}-$ without stabilizer; $2-d_{E}=0.005 \mathrm{~m}, S_{0}=0.18 \mathrm{~m}^{2} / \mathrm{m}^{2}-$ with stabilizer; $3-d_{E}=0.005 \mathrm{~m}, S_{0}=0.20 \mathrm{~m}^{2} / \mathrm{m}^{2}-$ with stabilizer

Increasing the area of the free segment leads to a decrease in efficiency (Figure 4). This confirms the correctness of the conclusions drawn in the analysis of the relationship of structural parameters.

An increase in the diameter of the grating holes 10 times when applied to the foam layer stabilization increases the efficiency of capturing ammonia by $20 \%$ compared to conventional gratings without stabilizing the layer and by $15 \%$ compared to conventional gratings with foam layer stabilization. It should be noted that the rate of gas processing in the investigated range from 2 to $5 \mathrm{~m} / \mathrm{s}$ has virtually no effect on the magnitude of efficiency.

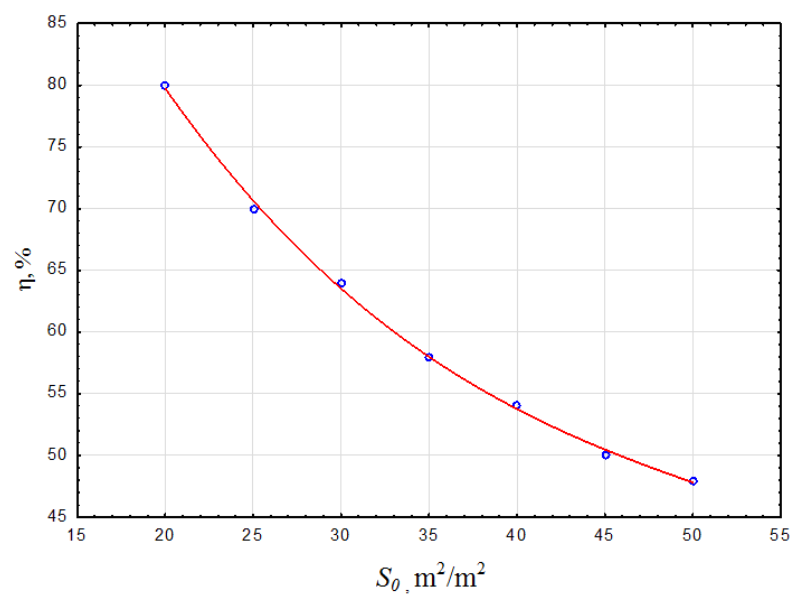

Figure 4 - Efficiency dependence at absorbing ammonia by water: $W_{g}=2.5 \mathrm{~m} / \mathrm{s} ; C_{n}=1-2 \% ; L_{0}=5 \mathrm{~m}^{3} /\left(\mathrm{m}^{2} \cdot \mathrm{h}\right)$

The character of change in the mass transfer coefficient, referenced to the grating area, from the linear gas velocity is given in Figure 5, from which it is evident that $W_{g}$ greatly affects $K_{s}$ in the investigated boundaries $W_{g}$. Processing the experimental data was obtained the following empirical equations for the calculation of $K_{s}, \mathrm{~m} / \mathrm{h}$ :

$$
K_{s}=1659,8 W_{g}^{1,5} L_{0}^{0,12} d_{\AA}{ }^{0,26} S_{0}^{-0,71}
$$

To calculate the efficiency, \%:

$$
\eta=0,713 \cdot 10^{3} W_{g}^{-1,9} L_{0}^{0,30} d_{\AA}^{-0,34} K_{s}^{1,27}
$$

Border for changing parameters:

$$
\begin{aligned}
& W_{g}=2-4,0 \mathrm{~m} / \mathrm{h}, L_{0}=1-20 \mathrm{~m}^{3} / \mathrm{m}^{2} \cdot \mathrm{h} ; \\
& S_{0}=0,20-0,40 \mathrm{~m}^{2} / \mathrm{m}^{2}, d_{\AA}=0,02-0,08 \mathrm{~m} .
\end{aligned}
$$

The error of calculating by equations (1) and (2) is not more than $9 \%$.

The influence of hydrodynamic parameters on the mass transfer coefficient at ammonia absorption by water is given in Fig. 6, which confirms the sufficient accuracy of the obtained equations, while the dependence of the mass transfer coefficient on the height of the foam layer is described by the following equation:

$$
K_{s}=4742 \cdot W_{g} H^{0,33}
$$

Border for changing parameters:

$$
W_{g}=2-4,0 \mathrm{~m} / \mathrm{h}, L_{0}=1-20 \mathrm{~m}^{3} / \mathrm{m}^{2} \mathrm{~h} \text {; }
$$$$
S_{0}=0,20-0,4 \mathrm{~m}^{2} / \mathrm{m}^{2}, d_{\AA}=0,02-0,08 \mathrm{~m}
$$

Equation (3) allows us to evaluate the mass transfer process under any hydrodynamic conditions, which is very important in the development and evaluation of technological schemes in industrial conditions with the use of new devices.

Experimental data confirmed the dependence obtained $[1,5]$ by Mukhlennov I. P.on the basis of theoretical consideration of the mass transfer in the foam layer for wellsoluble gases, which is expressed by the equation:

$$
K_{s}=n H^{0,33}
$$




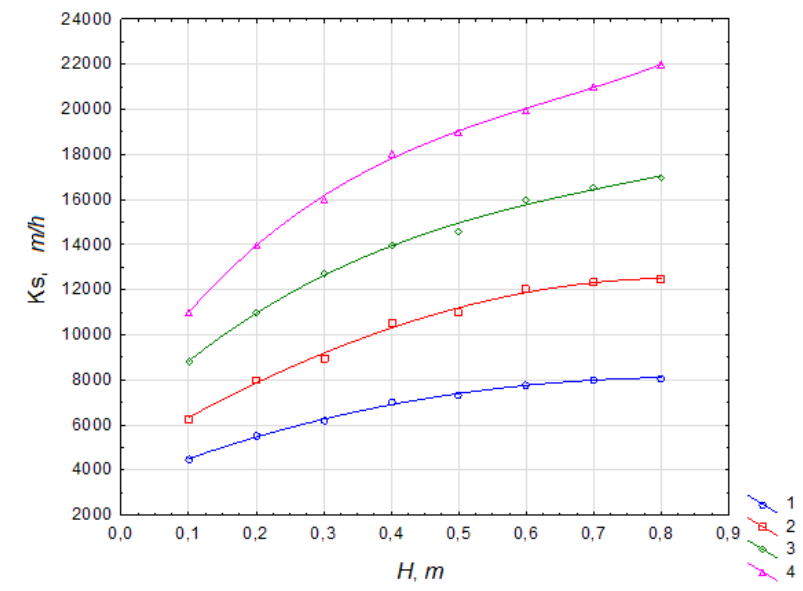

Figure 5 - Dependence of mass transfer coefficient, referenced to the grading area from the height of the gas-liquid layer at different gas velocities: $1-W_{g}=2 \mathrm{~m} / \mathrm{s} ; 2-W_{g}=3 \mathrm{~m} / \mathrm{s}$; $3-W_{g}=4 \mathrm{~m} / \mathrm{s} ; 4-W_{g}=5 \mathrm{~m} / \mathrm{s}$

Figure 6 shows the dependence of the actual mass transfer coefficient on the linear gas velocity, which implies that an increase in speed leads to an increase in the mass transfer coefficient.

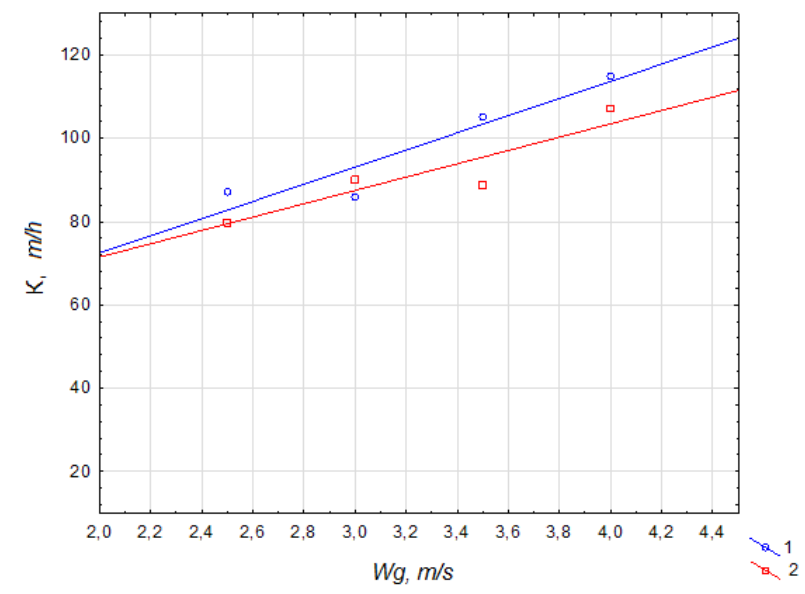

Figure 6 - Dependence of the actual mass transfer coefficient on the linear gas velocity (with stabilization) at absorbing ammonia by water: $1-$ grid $S_{0}=0.25 \mathrm{~m}^{2} / \mathrm{m}^{2} ; d_{E}=0.005 \mathrm{~m}$,

$L_{0}=5 \mathrm{~m}^{3} /\left(\mathrm{m}^{2} \cdot \mathrm{h}\right) ; 2-\operatorname{grid} S_{0}=0.18 \mathrm{~m}^{2} / \mathrm{m}^{2} ; d_{E}=0.005 \mathrm{~m} ;$

$$
L_{0}=5 \mathrm{~m}^{3} /\left(\mathrm{m}^{2} \cdot \mathrm{h}\right)
$$

It should be noted that the value of the true mass transfer coefficient for apparatus with ordinary and coarse hinged gratings with stabilization of the foam layer is approximately the same.

This confirms that the contact surface of phases in the foam layer on coarse-grained grates is 1.5 times higher at a gas velocity of more than $3 \mathrm{~m} / \mathrm{s}$ with an increase in the diameter of the grating holes 10 times, and confirms the possibility of efficient gas cleaning in the industry using foam machines.

\section{Discussion}

In order to verify the results obtained during bench tests in laboratory conditions, a cycle of pilot-industrial tests was conducted in which the main gas components were ammonia, fluoride compounds (mainly silicon tetra fluoride). In the system of purifying gases from the spray dryer, a reconstruction of the existing absorber was carried out (hollow scrubber with three tiers of nozzles). Instead of nozzles in the scrubber case, a contact step with coarse hole gratings (the holes are $0.045 \times 0.045 \mathrm{~m}$ and $S_{0}=0.28 \mathrm{~m}^{2} / \mathrm{m}^{2}$ ) and a foam layer stabilizer were installed (size $40 \times 40 \times 60 \mathrm{~mm}$ ).

Hydrodynamic tests were initially performed, which showed that the foam absorber has stable hydrodynamic characteristics when changing the gas velocity in the free intersection of the device from 3.5 to $5.5 \mathrm{~m} / \mathrm{s}$ at $L_{0}=8 \mathrm{~m}^{3} /\left(\mathrm{m}^{2} \cdot \mathrm{h}\right)$. The highly developed gas-liquid layer on the grating is present even at speeds less than $2.2 \mathrm{~m} / \mathrm{s}$. Measurement of the gas height -liquid layer in industrial conditions was carried out by electro-sharpening method. It should be noted at the same time that the measurements also showed good convergence with bench tests in laboratory conditions (Figure 7).

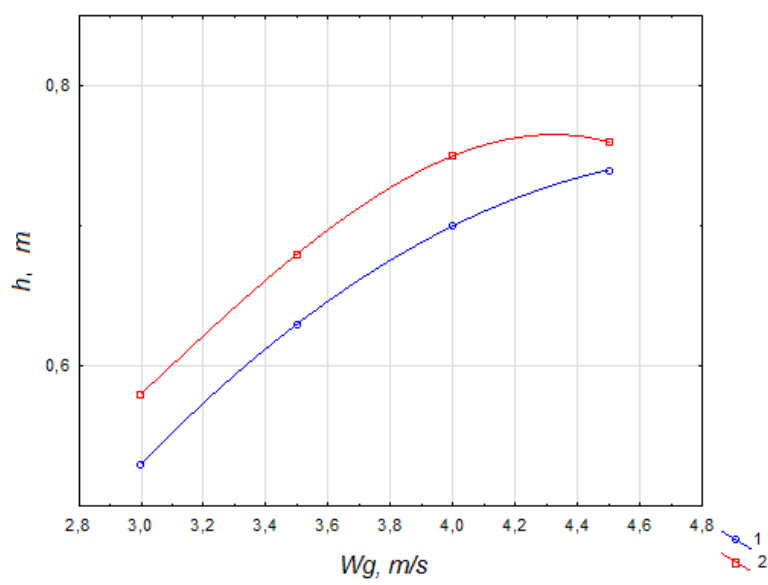

Figure 7 - Dependence of the foam layer height on the linear gas velocity of the apparatus (experimental and industrial tests): gas-pulp system with $\rho=1.22 \mathrm{~kg} / \mathrm{m}^{3}, L_{0}=8 \mathrm{~m}^{3} /\left(\mathrm{m}^{2} \cdot \mathrm{h}\right)$ :

1 - experimental-industrial tests $S_{0}=0.28 \mathrm{~m}^{2} / \mathrm{m}^{2} ; d_{E}=0.048 \mathrm{~m}$; 2 - bench tests $S_{0}=0.25 \mathrm{~m}^{2} / \mathrm{m}^{2} ; d_{E}=0.05 \mathrm{~m}$

On this basis, for this technological scheme, optimal hydrodynamic mode of gas processing was determined which corresponded to the linear gas velocity from 3.0 to $4.9 \mathrm{~m} / \mathrm{s}$ [6].

At these hydrodynamic parameters technological regimes for capturing ammonia, fluoride compounds and dust, depending on the acidity of ammonium phosphates, and also parameters in the existing technological scheme were analyzed in parallel (Figure 8). 


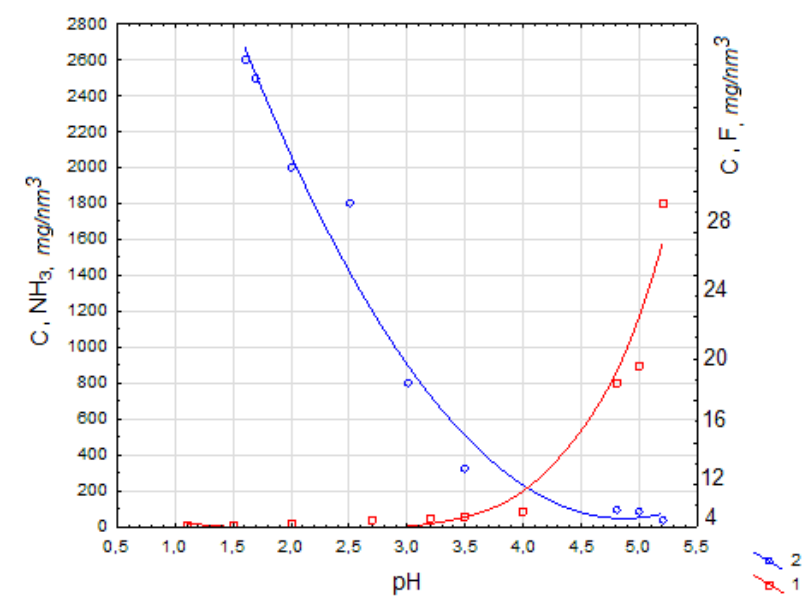

Figure 8 - Dependence of the $\mathrm{NH}_{3}$ final content and fluoride compounds on the acidity of the irrigation solution: $W_{g}=4 \mathrm{~m} / \mathrm{s}$; $L_{0}=8 \mathrm{~m}^{3} /\left(\mathrm{m}^{2} \cdot \mathrm{h}\right) ; 1-$ ammonia; 2 - fluoride compounds, $C_{N_{4}}=1.0 \mathrm{~g} / \mathrm{nm}^{3}, C_{H F}=0.1 \mathrm{~g} / \mathrm{nm}^{3}$, grid: $S_{0}=28 \%$,

$$
d_{E}=0.045 \mathrm{~m}
$$

Figure 9 shows the dependence of the gas purification efficiency from ammonia and fluoride compounds from the acidity of the pulp, and it is evident that the degree of absorption of ammonia and fluoride compounds depends on the acidity of the irrigation solution. At $\mathrm{pH}$ of a solution equal to 1.4 , for ammonia, the degree of absorption is $98 \%$, and for fluoride compounds at $\mathrm{pH}=5.7$, the efficiency is $94 \%$.

\section{Conclusions}

The conducted studies indicate the possibility of deep cleaning and virtually complete removal of harmful components from gases in their separate absorption. Dependences of NH3 final content and fluorine in the gas after treatment from ammonium phosphate acidity are shown in Figure 9, from which it is evident that the optimal mode for the absorption of these components lies within the $\mathrm{pH}$ of the solution from 3 to 5 . In this case, the maximum permissible emission rates for ammonia are maintained. This is confirmed by the high mass exchange characteristics of the developed foam device, allowing the process of joint and effective cleaning of these components in the range of $\mathrm{pH}$ irrigating solution from 3 to 5 . As a result of experimental and industrial tests, it is

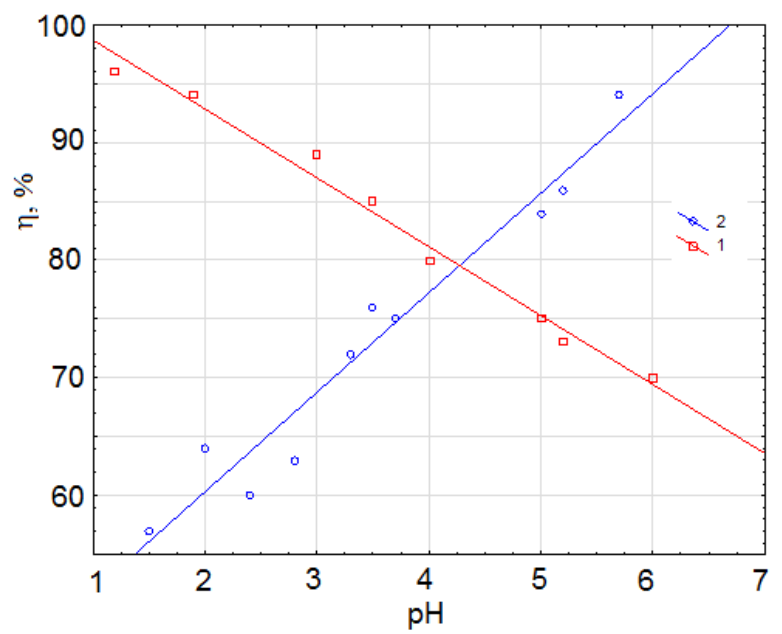

Figure 9 - Dependence of $\mathrm{NH}_{3}$ absorption rate and fluoride compounds on the acidity of the irrigation solution:

$L_{0}=8 \mathrm{~m}^{3} /\left(\mathrm{m}^{2} \cdot \mathrm{h}\right) ; 1$ - ammonia; 2 - fluoride compounds, initial concentration of ammonia $1.0 \%$ vol.; $W_{g}=4 \mathrm{~m} / \mathrm{s}$; grid $S_{0}=0.28 \mathrm{~m}^{2} / \mathrm{m}^{2}, d_{E}=0.045 \mathrm{~m}$

established the following: the efficiency of dust capture practically does not depend on the $\mathrm{pH}$ of the solution and also on the increase of the inlet dust to $4-6 \mathrm{~g} / \mathrm{nm}^{3}$. Increasing the density of the circulating pulp of ammonium phosphates does not affect the efficiency.

The conducted studies have experimentally confirmed the possibility of effective mass exchange processes in an intensive foam layer on counter currently coarse hinged gratings.

The application of new apparatus allows radically reconstructing, with minimal cost, technological schemes for gas cleaning in the chemical and other industries to provide them with better operational and technological characteristics, while simultaneously increasing the efficiency of working with concentrated solutions, their circulation and use in the main process [7].

\section{Acknowledgements}

The main results were obtained within the research project of Sumy State University "Development and implementation of energy efficient modular separation devices for oil and gas purification equipment" (State Reg. No. 0117U003931) ordered by the Ministry of Education and Science Ukraine. 


\title{
References
}

1. Muhlenova, I. P., \& Tarata, E. Ya. (1977). Foam mode and foam devices. Moscow, Chemistry.

2. Tarat, E. Ya., Balabekov, O. S., \& Bolgov, N. P. (1976). Intensive colony machines for handling gases with liquids. SaintPetersburg State University.

3. Moiseev, V. F., Manoylo, E. V., Repko, K. Yu., \& Davydov, D. V. (2017). Treatment of gas-discharge systems on tubular lattices with foam layer stabilizer. Bulletin of the National Technical University "Kharkiv Polytechnic Institure", Series "New solutions in modern technologies", No. 53, pp. 114-123, doi: 10.20998/2413-4295.2017.53.17.

4. Moiseev, V. F., Manoylo, Ye. V., Ponomareva, N. G., Repko, K. Yu., \& Davydov, D. V. (2018). Methodology for calculation of regime-constructive and hydrodynamic parameters of foam devices for mass transfer processes. Bulletin of the National Technical University "Kharkiv Polytechnic Institure”, Series "New Solutions in Modern Technologies", No. 16, pp. 165-176, doi: 10.20998/2413- 4295.2018.16.25.

5. Muhlenova, I. P., \& Kovalev, O. S. (1987). Absorption and dust extraction in the production of mineral fertilizers. Moscow, Chemistry.

6. Moiseev, V. F., Manoylo, Ye. V., Lyaposhenko, O. O., Khukhryansky, O.M., \& Ponomareva, N. G. (2018). Structure of foam layer on counteracting contact elements with stabilization. Bulletin of the National Technical University "Kharkiv Polytechnic Institure”, Series “New solutions in modern technologies", No. 26, pp. 83-92, doi: 10.20998/2413-4295.2018.26.37.

7. Perry, D. C., \& Stevenson, P. (2015). Gas absorption and reaction in a wet pneumatic foam. Chemical Engineering Science, Vol. 126, pp. 177-185, doi: 10.1016/j.ces.2014.11.037.

\section{Дослідження інтенсифікованих пінних апаратів із крупнодірчастими гратками}

\author{
Liaposhchenko O. ${ }^{1 *}$, Khukhryanskiy O. ${ }^{1,2}$, Moiseev V. ${ }^{3}$, Ochowiak M. ${ }^{4}$, Manoilo E. ${ }^{3}$ \\ ${ }^{1}$ Сумський державний університет, вул. Римського-Корсакова, 2, 40007, м. Суми, Україна; \\ ${ }^{2}$ ПАТ «Укрхімпроект», вул. Іллінська, 13, 40009, м. Суми, Україна; \\ ${ }^{3}$ Національний технічний університет «Харківський політехнічний інститут», \\ вул. Кирпичова, 2, 61002, м. Харків, Україна; \\ ${ }^{4}$ Технологічний університет м. Познань, пл. М. Склодовської-Кюрі, 5, 60-965, м. Познань, Польща
}

Анотація. У роботі досліджувалися укрупнені моделі пінних апаратів з гратками, зібраними 3 трубок різного діаметра. Розглядаються питання інтенсифікації пінних апаратів із застосуванням крупнодірчастих граток. Відзначена можливість глибокого очищення і практично повного очищення газів від аміаку i фтористих з'єднань при їх роздільній абсорбції. Наведено ряд експериментальних залежностей основних параметрів процесу. Підтверджена можливість ефективного проведення масообміних процесів в інтенсивному пінному шарі на протитечійних крупнодірчастих гратках.

Ключові слова: викиди промислових газів, гідродинаміка, масообмін, пінний апарат, пінний шар, процес очищення, стабілізація пінного шару, інтенсифікація процесу. 